IP Periodica Polytechnica Chemical Engineering

59(4), pp. 262-271, 2015

DOI: 10.3311/PPch.8077

Creative Commons Attribution (1)

RESEARCH ARTICLE

\section{Assessing Toxicity of Organic Aquatic Micropollutants Based on the Total Chlorophyll Content of Lemna minor as a Sensitive Endpoint}

\author{
Ildikó Fekete-Kertész ${ }^{1 *}$, Zsuzsanna Kunglné-Nagy ${ }^{1}$, Katalin Gruiz ${ }^{1}$,
} Ádám Magyar ${ }^{1}$, Éva Farkas ${ }^{1}$, Mónika Molnár ${ }^{1}$

Received 12 March 2015; accepted after revision 22 April 2015

\begin{abstract}
The present study examined the chlorophyll content in a 7-day contact time experiment series. Lemna minor was exposed to caffeine, benzophenone, bisphenol A, 3,4-dichlorophenol, metamizole-Na, Na-diclofenac, acetochlor, atrazine, diuron, metazachlor and metolachlor to find a convenient sensitive response to the tested chemicals including some emerging micropollutants. The results demonstrated the differences in sensitivity to the tested micropollutants. As anticipated the industrial chemicals and the pesticides were the most toxic. The lowest observed effect concentration (LOEC) values determined for 3,4-dichlorophenol, acetochlor, diuron, metazachlor and metolachlor were $2.5 \mu \mathrm{g} / \mathrm{L}, 0.05 \mu \mathrm{g} / \mathrm{L}, 0.5 \mu \mathrm{g} / \mathrm{L}, 5 \mu \mathrm{g} / \mathrm{L}$ and $0.5 \mu \mathrm{g} / \mathrm{L}$, respectively. These values were comparable with the environmental concentrations reported in literature. Our study provides valuable information on the feasibility of Lemna minor total chlorophyll method as a sensitive and reliable bioassay for testing toxicity at $\mu \mathrm{g} / \mathrm{L}$ range and it may support risk assessment of organic micropollutants in freshwater ecosystems.
\end{abstract}

\section{Keywords}

Lemna minor, chlorophyll content, emerging micropollutants, pesticides, pharmaceuticals, industrial additives

\section{Introduction}

Pollution of the aquatic ecosystems is a serious problem worldwide. Many articles report about micropollutants found in treated wastewaters, drinking water and surface or subsurface waters at trace concentrations. These chemical substances represent possible environmental and human health risk [1-4]. Emerging pollutants (EPs) are referred to as new chemicals because they have recently been analyzed and their impact on human health and environment are not understood properly [5]. The main sources of these emerging pollutants and pesticides are from industrial, municipal and agricultural applications [1-3,6]. Municipal wastewaters and hospital effluents may contain pharmaceuticals, personal care products (PPCPs), industrial additives and pesticides, etc. which cannot be eliminated by the conventional wastewater treatment technologies [7-13].

Many micropollutants and the above mentioned EPs have no regulatory status and most of them are not considered priority pollutants of concern. So the importance of detecting contaminants in the environment and studying their impacts has resulted in the development and adoption of numerous chemical analytical and ecotoxicological methods $[14,15]$. Chemical analytical methods have several limitations. The chemical analytical methods do not take into account changes in exposure and availability of pollutants therefore they do not provide ecologically relevant information. Moreover the sample preparation is a complex procedure and chemical analysis needs expensive equipment and reagents $[16,17]$. To compensate these drawbacks numerous ecotoxicological tests including also plants tests have been developed and applied to investigate the adverse effects of the above mentioned chemical substances [4,16,18-21].

The objective of this work was to identify the environmental toxicity of different micropollutants, especially emerging pollutants and pesticides to the Lemna minor aquatic macrophyte.

Aquatic and terrestrial plants are sensitive test organisms to numerous environmental pollutants and have been used for monitoring the toxic effects in water quality studies. Freshwater plants are considered usually less sensitive to chemicals than animal species, but aquatic macrophytes were found to be more sensitive to some toxic metals and pesticides than fish $[22,23]$. 
Duckweeds (Lemnaceae) are key components of freshwater ecosystems. Lemna minor compared to algae is a new test organism, which is widespread all over the world; it is a vascular plant floating on the water surface. Two different species are widely applied in ecotoxicity studies, the L. minor and L. gibba. Because of its small size, simple structure (root and leaves) and thanks to its vegetative propagation and easy cultivation $L$. minor is an ideal test organism. The doubling time of the leaves is between $0.35-2.8$ days, the tests are simple and cost effective. There are a number of different test methods applying $L$. minor for environmental toxicology assessment. The duration of these tests is usually $4-7$ days. The most commonly measured parameters are the frond number, biomass production, leaf diameter and root length [24,25].

In recent years, scientists have primarily dealt with the effects of heavy metals on Lemna species, using different measurement endpoints. Drost et al. [26] studied the effect of heavy metals applying fluctuating concentrations in time, thereby modelling the exposure of the test organism to varying pollutant concentrations in the environment. They found that at low pollutant concentrations a so-called recovery phase occurs. After 7 days of exposure $\mathrm{Cd}$ and $\mathrm{Cu}$ resulted in $\mathrm{EC}_{50}=1.9$ and $9.7 \mu \mathrm{M}$ respectively, $\mathrm{Ni}$ and $\mathrm{Zn}$ resulted in $\mathrm{EC}_{50}=56.3$ and $46.1 \mu \mathrm{M}$ respectively in case of growth rate toxicity endpoint. Dirilgen [27] found that the simultaneous application of lead and mercury caused synergistic toxic effects on L. minor growth rate, mutually reinforcing each other.

The $\mathrm{EC}_{50}(7$ days) value for $\mathrm{Pb}$ was $5.5 \mathrm{mg} / \mathrm{L}$, while the $\mathrm{EC}_{50}(7$ days $)$ value for $\mathrm{Hg}$ was $0.48 \mathrm{mg} / \mathrm{L}$. Horvat et al. [28] studied the feasible utility of $L$. minor for multi-component samples containing heavy metals. The applied toxicity endpoints were relative growth rate, Nfronds/Ncolonies ratio, dry to fresh weight ratio and frond area. They also measured guaiacol peroxidase activity as early indicator of oxidative stress. Their results indicate that not only single-component samples, but multi-component samples containing heavy metals can be studied successfully. Park et al. [17] developed, proposed and applied a novel method applying root re-growth as a sensitive endpoint for testing toxicity of metals. For $\mathrm{Ag}$ the $\mathrm{EC}_{50}$ value was $5.3-37.6 \mu \mathrm{g} / \mathrm{L}$, for $\mathrm{Cu} \mathrm{EC}_{50}=470.4 \mu \mathrm{g} / \mathrm{L}$. Gubbins et al. [29] studied the toxic effects of nano-silver on L. minor, the results showed that nanomaterials may have harmful effects on the ecosystem. $5 \mu \mathrm{g} / \mathrm{L}$ silver nanoparticle caused inhibition of plant growth which became higher with a longer exposure time. Radic et al. [20] determined the toxicity and genotoxicity of surface water samples using $L$. minor applying growth parameters and other endpoints such as pigment content, peroxidase activity, lipid peroxidation and alkaline comet assay. Juneau et al. [30] determined the toxicity of various water samples measuring the total chlorophyll fluorescence of L. gibba. An alga species (C. ehrenbergii) proved to be 400 times more sensitive to hydrophobic components than L. gibba.
The single or joint toxicity of different pesticides and degradation products to the aquatic environment has been also widely investigated/tested using Lemna species [16,21,31-35]. Toxic effect of pesticides was generally evaluated by growth inhibition, but sometimes the sensitivity of this endpoint was not adequate compared to the environmentally realistic effect concentration values.

Currently, little literature is available on the potential hazardous effect of emerging pollutants on Lemna species. Although Cedergreen et al. [36] and Gorzerino et al. [37] tested the toxicity of various pesticides on L. minor, their studies did not cover any emerging pollutant type such as pharmaceuticals, industrial additives and agents or personal care products.

Brain et al. [38] studied eight different pharmaceuticals (atorvastatin, acetaminophen, caffeine, sulfamethoxazole, carbamazepine, levofloxacin, sertraline, and trimethoprim). In case of $L$. gibba a clear concentration-effect was observed.

Table 1 shows the Lowest Observed Effect Concentration (LOEC), the No Observed Effect Concentration (NOEC) and the median effective concentration $\left(\mathrm{EC}_{50}\right)$ data from current literature concerning the investigated substances in our research.

Concerning these facts L. minor is a promising test organism to study the effect of micropollutants. The main objective of our study was to provide information on different micropollutants including several emerging compounds and pesticides applying the total chlorophyll content as endpoint in the Lemna minor growth assay, which according to the current literature is scarcely applied for the testing of micropollutants.

Table 1 Selected $\mathrm{EC}_{50}$, NOEC and LOEC values from current literature about the freshwater toxicity of the tested micropollutants on Lemna minor and Lemna gibba

\begin{tabular}{|c|c|c|c|c|}
\hline $\begin{array}{l}\text { Chemical } \\
\text { substance }\end{array}$ & $\begin{array}{l}\text { Ecotoxicity } \\
\text { parameter }\end{array}$ & Concentration & Endpoint & Ref \\
\hline Caffeine & LOEC (7 d) & $0.608 \mu \mathrm{mol} / \mathrm{L}$ & frond number ${ }^{1}$ & {$[38]$} \\
\hline Caffeine & $\mathrm{EC}_{50}(7 \mathrm{~d})$ & $12.3 \mu \mathrm{mol} / \mathrm{L}$ & chlorophyll-a $^{1}$ & {$[38]$} \\
\hline Caffeine & $\mathrm{EC}_{50}(7 \mathrm{~d})$ & $5.38 \mu \mathrm{mol} / \mathrm{L}$ & chlorophyll-b ${ }^{1}$ & {$[38]$} \\
\hline Bisphenol A & $\mathrm{EC}_{50}(7 \mathrm{~d})$ & $32 \mathrm{mg} / \mathrm{L}$ & growth rate ${ }^{1}$ & {$[40]$} \\
\hline Bisphenol A & $\operatorname{NOEC}(7 \mathrm{~d})$ & $7.8 \mathrm{mg} / \mathrm{L}$ & frond biomass ${ }^{1}$ & {$[40]$} \\
\hline Diclofenac & $\mathrm{EC}_{50}(7 \mathrm{~d})$ & $7.5 \mathrm{mg} / \mathrm{L}$ & total frond area ${ }^{2}$ & {$[41]$} \\
\hline Diclofenac & $\mathrm{EC}_{50}(7 \mathrm{~d})$ & $47.6 \mu \mathrm{g} / \mathrm{L}$ & $\begin{array}{l}\text { population } \\
\text { abundance }^{2}\end{array}$ & {$[42]$} \\
\hline Acetochlor & $\mathrm{EC}_{50}(14 \mathrm{~d})$ & $3.4 \mu \mathrm{g} / \mathrm{L}$ & $\begin{array}{l}\text { population } \\
\text { abundance }^{1}\end{array}$ & {$[43]$} \\
\hline Atrazine & $\mathrm{EC}_{50}(10 \mathrm{~d})$ & $56 \mu \mathrm{g} / \mathrm{L}$ & $\begin{array}{c}\text { abundance, frond } \\
\text { number }^{2}\end{array}$ & {$[44]$} \\
\hline Diuron & $\mathrm{EC}_{50}(7 \mathrm{~d})$ & $28.3 \mu \mathrm{g} / \mathrm{L}$ & frond number ${ }^{2}$ & {$[31]$} \\
\hline Metazachlor & $\mathrm{EC}_{50}(7 \mathrm{~d})$ & $2.8 \mu \mathrm{g} / \mathrm{L}$ & frond area ${ }^{2}$ & {$[45]$} \\
\hline Metolachlor & $\mathrm{EC}_{50}(5 \mathrm{~d})$ & $21 \mu \mathrm{g} / \mathrm{L}$ & $\begin{array}{l}\text { population } \\
\text { abundance }^{1}\end{array}$ & {$[43]$} \\
\hline
\end{tabular}

${ }^{1}$ Test organism: Lemna gibba

${ }^{2}$ Test organism: Lemna minor 


\section{Materials and methods}

\subsection{Chemicals}

Nicotine (N0267-100MG, $\geq 99 \%$ TLC liquid, CASRN: 54-11-5), 3,4-dichlorophenol (99\%, D70406-5G, CASRN: 95-77-2); benzophenone (B9300-25G-A, 99\%, CASRN: 11961-9), metolachlor (36163-100MG-PESTANAL ${ }^{\circledR}$, analytical standard-FLUKA, CASRN: 51218-45-2), bisphenol A (23965850G, $\geq 99 \%$, CASRN: 80-05-7), Na-diclofenac (D6899-10G, CASRN: 15307-79-6) and acetochlor (33379-100MG-PESTA$\mathrm{NAL}^{\circledR}$, analytical standard-FLUKA, CASRN: 34256-82-1) were purchased from Sigma Aldrich; Metazachlor (Sultan 50SC, CASRN: 67129-08-2) was purchased from Makhteshim-Agan Industries Ltd. Israel with $500 \mathrm{~g} / \mathrm{L}$ metazachlor content. Atrazine (>97.0\%, CASRN: 1912-24-9) and diuron (>97.0\%, CASRN: 330-54-1) were supported by KISCHEMICALS Manufacturing and Mercantile LLC. Caffeine (CASRN: 58-08-2) and Metamizole-Na (CASRN: 8017-81-0) pharmaceutical drug were manufactured by Sanofi-Aventis Ltd. at Veresegyház (Hungary).

Standard solutions were prepared from these chemical substances according to their water solubility. The standard solutions were introduced without further treatment into the test systems. Table 2 contains the applied nominal concentrations of test substances.

Table 2 Applied nominal concentrations of the tested micropollutants and pesticides

\begin{tabular}{cc}
\hline Test substance & Nominal concentration $[\mathbf{m g} / \mathbf{L}]$ \\
\hline Caffeine & $0.01 ; 0.1 ; 1 ; 10 ; 100$ \\
Benzophenone & $1.5635 ; 3.125 ; 6.25 ; 12.5 ; 25$ \\
Bisphenol A & $1.5635 ; 3.125 ; 6.25 ; 12.5 ; 25$ \\
3,4-dichlorophenol & $0.000025 ; 0.00025 ; 0.0025 ; 0.025 ; 0.25 ; 2.5$ \\
Metamizole-Na & $3.125 ; 6.25 ; 12.5 ; 25 ; 50$ \\
Na-diclofenac & $0.00005 ; 0.0005 ; 0.005 ; 0.05 ; 0.5 ; 5$ \\
Acetochlor & $0.00001 ; 0.0001 ; 0.001 ; 0.01 ; 0.1 ; 1$ \\
Atrazine & $0.0005 ; 0.005 ; 0.05 ; 0.5 ; 5$ \\
Diuron & $0.0005 ; 0.005 ; 0.05 ; 0.5 ; 5 ; 50$ \\
Metazachlor & $0.00005 ; 0.0005 ; 0.005 ; 0.05 ; 0.5 ; 5$ \\
Metolachlor &
\end{tabular}

\subsection{Test organism}

A colony of Lemna minor cultured in the laboratory was used in this experiment. The applied growth medium was the original Hoagland's nutrient medium (Missouri Botanical Garden). All salts were dissolved in distilled water. The test organism was cultured in a $20 \times 30 \times 7 \mathrm{~cm}$ glass container in a $21.5 \pm 1^{\circ} \mathrm{C}$ thermostat with 16:8 hr light: dark cycle (illumination: Juwel Aquarium, Day-Lite, 15W, 438 mm lamp, 560 Lumen, $6500 \mathrm{~K}$ ). Healthy, two-leaf L. minor individuals cultivated in Hoagland's nutrient medium were used for the test.
Hoagland's nutrient medium

$\mathrm{MgSO}_{4} \cdot 7 \mathrm{H}_{2} \mathrm{O}(24.6 \mathrm{~g} / 100 \mathrm{~mL})$ :

$1.0 \mathrm{~mL} / \mathrm{L}$

$\mathrm{Ca}\left(\mathrm{NO}_{3}\right)_{2} \cdot 4 \mathrm{H}_{2} \mathrm{O}(23.6 \mathrm{~g} / 100 \mathrm{~mL})$ :

$2.3 \mathrm{~mL} / \mathrm{L}$

$\mathrm{KH}_{2} \mathrm{PO}_{4}(13.6 \mathrm{~g} / 100 \mathrm{~mL})$ :

$0.5 \mathrm{~mL} / \mathrm{L}$

$\mathrm{KNO}_{3}(10.1 \mathrm{~g} / 100 \mathrm{~mL})$ :

$2.5 \mathrm{~mL} / \mathrm{L}$

Microelement solution:

$0.5 \mathrm{~mL} / \mathrm{L}$

Fe-EDTA solution:

$20.0 \mathrm{~mL} / \mathrm{L}$

Microelement solution:

$\mathrm{H}_{3} \mathrm{BO}_{3}$

$2.86 \mathrm{~g} / \mathrm{L}$

$\mathrm{MnCl}_{2} \cdot 4 \mathrm{H}_{2} \mathrm{O}$

$\mathrm{Na}_{2} \mathrm{MoO}_{4} \cdot 2 \mathrm{H}_{2} \mathrm{O}$

$1.82 \mathrm{~g} / \mathrm{L}$

$\mathrm{CuSO}_{4} \cdot 5 \mathrm{H}_{2} \mathrm{O}$

$0.09 \mathrm{~g} / \mathrm{L}$

$\mathrm{ZnSO}_{4} \cdot 7 \mathrm{H}_{2} \mathrm{O}$

$0.09 \mathrm{~g} / \mathrm{L}$

$0.22 \mathrm{~g} / \mathrm{L}$

Fe-EDTA solution:

$\mathrm{FeCl}_{3} \cdot 6 \mathrm{H}_{2} \mathrm{O}$

$0.121 \mathrm{~g} / 250 \mathrm{~mL}$

EDTA

$0.375 \mathrm{~g} / 250 \mathrm{~mL}$

\subsection{Lemna minor bioassay}

The experiment was carried out with three parallels in $150 \mathrm{~cm}^{3}$ beakers. On the first day 10 healthy and two-leaf L. minor individuals were placed into $50 \mathrm{~mL}$ of each dilution member of the test solutions. Hoagland's nutrient medium was applied as control. The beakers were covered with a translucent plastic film to avoid evaporation and concentration of the test solutions during the experiment. The assembled test systems (beakers) were incubated in a $21,5 \pm 1{ }^{\circ} \mathrm{C}$ thermostat for 7 days under the following light conditions: $16: 8 \mathrm{hr}$ light:dark cycle (illumination: Juwel Aquarium, Day-Lite, 15W, 438 mm lamp, 560 Lumen, $6500 \mathrm{~K}$ ).

On the seventh day L. minor individuals were removed from the test solutions, then surface-dried on filter paper to constant weight. The dried biomass was placed into ground-necked test tubes containing $5 \mathrm{~mL}$ of $96 \%$ ethanol. After 24 hours the optical density of the samples was determined spectrophotometrically (Sanyo SP55 UV/VIS spectrophotometer) at 470, 649 and $664 \mathrm{~nm}$ wavelength values.

The total chlorophyll content was determined for all tested chemical substances. The tested chemical substances were dissolved in the original Hoagland's nutrient medium in a series of five or six members decimal or twofold dilution explained above.

For three selected model compounds (nicotine, Nadiclofenac and 3,4-dichlorophenol) the correlation between the frond number and the total chlorophyll content as measurement endpoints was also examined and evaluated in a preliminary experiment. The inhibition effect of nicotine, Nadiclofenac and 3,4-dichlorophenol on the frond number and the total chlorophyll content was followed and determined in a 7-day contact time experiment. 


\subsection{Evaluation and interpretation of results - statisti- cal analysis}

From the measured optical density values the total chlorophyll content was determined using the following formula [39]:

where:

$$
C_{a+b}=\left(5.24 * A_{664}+22.24 * A_{649}\right) * E
$$

$C_{a+b}$ : total chlorophyll content of the sample ( $\left.\mu \mathrm{g}\right)$

$A_{664}:$ absorbance values at $664 \mathrm{~nm}$ wavelength

$A_{649}$ : absorbance values at $649 \mathrm{~nm}$ wavelength

$E$ : the amount of $\mathrm{EtOH}(96 \%)$ applied for the extraction $(\mathrm{mL})$

One-way analysis of variance (ANOVA) was performed by STATISTICA $12 \AA$ software identifying significant effects $(p<0.05)$. Univariate Tests of Significance were performed and the homogeneity of variances was examined. In case of significance the lowest observed effects concentration value (LOEC) was determined using Dunnett's test $(\alpha=0.05)$.

\section{Results}

The correlation between the frond number and the total chlorophyll content was determined in a preliminary experiment. We found, that there is a linear correlation $(y=0.648 x$ $-0.0572 ; R^{2}=0.9774$ ) between frond number and total chlorophyll content in the control (uncontaminated) samples.

But three selected model compounds (Na-diclofenac, nicotine and 3,4-dichlorophenol) caused higher inhibition of the chlorophyll content than of the frond number (Fig. 1). These chemicals may have caused chlorosis manifested in the loss of chlorophyll content however not yet necrosis and disintegration in fronds of the affected plants.

Thus, in case of Na-diclofenac, nicotine and 3,4-dichlorophenol the chlorophyll content proved to be a more sensitive endpoint than the conventionally applied frond number.

The effect of 5 pesticides (metazachlor, acetochlor, metolachlor, atrazine and diuron) and 5 other micropollutants (caffeine, metamizole-Na, Na-diclofenac, bisphenol A and benzophenone) on the total chlorophyll content was determined. The following STATISTICA 12 BoxPlot diagrams show the effect of the micropollutants on Lemna minor at different concentrations where 0 refers to the control group. From these diagrams we can see which concentration caused significant decrease in the total chlorophyll content compared to the total chlorophyll content of the control group (Fig. 2-3).

As shown in Fig. 2-3 concentration-dependent declines were observed in the chlorophyll content only in case of benzophenone and bisphenol A. In case of caffeine, 3,4-dichlorophenol, metamizol-Na and most pesticides the chlorophyll content did not show monotonic concentration dependence with the exposure to the substances but showed statistically significant high toxicity at $\mu \mathrm{g} / \mathrm{L}$ concentration level compared to the control group.

Table 3 shows the inhibition percentage values $(\mathrm{H} \%)$ at different concentrations of the applied micropollutants. In case of Na-diclofenac inhibitory effect was detected $(\mathrm{H} \%=33-38)$ at
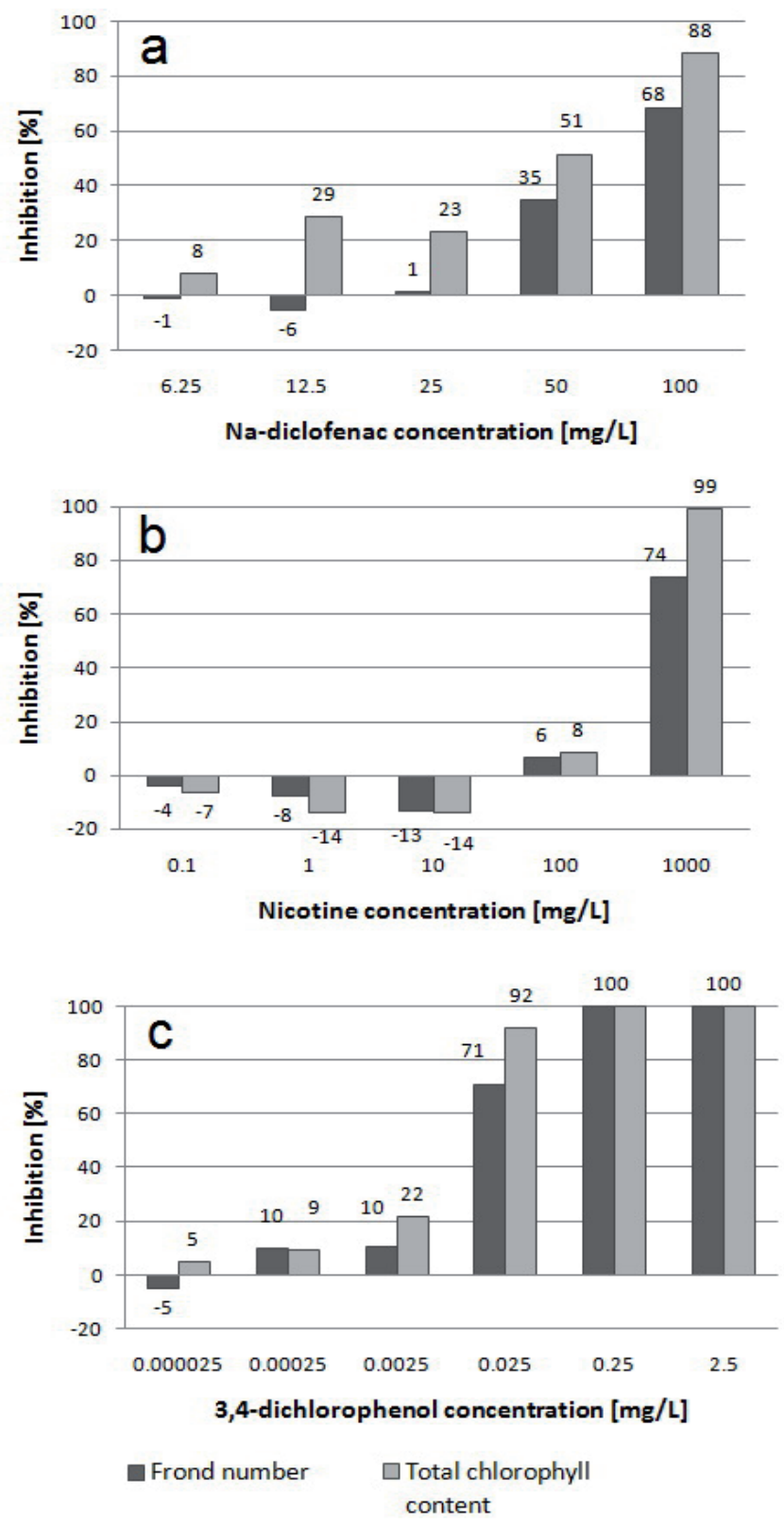

Fig. 1 Inhibition effect of Na-diclofenac (a), nicotine (b) and 3,4-dichlorophenol (c) on the frond number and the total chlorophyll content expressed in inhibition percentage $(\mathrm{H} \%)$.

all tested concentrations $(3.125-50 \mathrm{mg} / \mathrm{L})$, except for $25 \mathrm{mg} / \mathrm{L}$ Na-diclofenac, which caused $65 \mathrm{H} \%$. In case of caffeine at $0.01 \mathrm{mg} / \mathrm{L}$ concentration $28 \%$ inhibitory effect could be detected. $1.5625 \mathrm{mg} / \mathrm{L}$ benzophenone solution resulted in 53\% inhibition, while in case of bisphenol A $12 \%$ inhibition effect was detected at $1.5625 \mathrm{mg} / \mathrm{L}$ concentration level. $0.01 \mathrm{mg} / \mathrm{L}$ metamizole$\mathrm{Na}$ solution caused $45 \%$ inhibition. Metazachlor resulted in 84-93 $\mathrm{H} \%$ at $0.0005-50 \mathrm{mg} / \mathrm{L}$ concentration range. $0.0025 \mathrm{mg} / \mathrm{L}$ 3,4-dichlorophenol solution resulted in $22 \mathrm{H} \%$, while 0.025 $2.5 \mathrm{mg} / \mathrm{L}$ concentration caused $92-100 \mathrm{H} \% .0 .05 \mu \mathrm{g} / \mathrm{L}$ acetochlor caused $94 \mathrm{H} \%$, while $0.05 \mu \mathrm{g} / \mathrm{L}$ metolachlor caused $11 \mathrm{H} \% .0 .5 \mu \mathrm{g} / \mathrm{L}$ Metolachlor at $0.5 \mu \mathrm{g} / \mathrm{L}$ concentration resulted in $47 \mathrm{H} \% .0 .1$ and $1 \mathrm{mg} / \mathrm{L}$ atrazine solution resulted in 71 and $85 \mathrm{H} \%$ respectively. Diuron caused $33 \mathrm{H} \%$ at $0.0005 \mathrm{mg} / \mathrm{L}$ concentration, but $0.5 \mathrm{mg} / \mathrm{L}$ diuron solution resulted in $86 \mathrm{H} \%$. 
Table 3 Inhibition effect on the total chlorophyll content of the tested micropollutants in inhibition percentages (H\%)

\begin{tabular}{ccccccccccc}
\hline $\begin{array}{c}\text { Conc. } \\
{[\mathbf{m g} / \mathbf{L}]}\end{array}$ & Caffeine & $\mathbf{m g} / \mathbf{L}$ & Benzophenone & Bisphenol A & $\mathbf{m g} / \mathbf{L}$ & $\begin{array}{c}\mathbf{3 , 4 - d i c h l o r o -} \\
\mathbf{p h e n o l}\end{array}$ & $\mathbf{m g} / \mathbf{L}$ & Metamizole-Na & $\mathbf{m g} / \mathbf{L}$ & Na-diclofenac \\
\hline- & - & - & - & - & 0.000025 & 5 & - & - & - \\
0.01 & 28 & 1.5625 & 53 & 12 & 0.00025 & 9 & 0.01 & 45 & 3.125 & 36 \\
0.1 & 41 & 3.125 & 52 & 13 & 0.0025 & 22 & 0.1 & 35 & 6.25 & 38 \\
1 & 38 & 6.25 & 56 & 35 & 0.025 & 92 & 1 & 57 & 12.5 & 33 \\
10 & 44 & 12.5 & 87 & 46 & 0.25 & 100 & 10 & 53 & 25 & 64 \\
100 & 51 & 25 & 91 & 88 & 2.5 & 100 & 100 & 47 & 50 & 37 \\
\hline
\end{tabular}

\begin{tabular}{|c|c|c|c|c|c|c|c|c|c|}
\hline $\begin{array}{l}\text { Conc. } \\
{[\mathrm{mg} / \mathrm{L}]}\end{array}$ & Acetochlor & $\mathrm{mg} / \mathrm{L}$ & Atrazine & $\mathrm{mg} / \mathrm{L}$ & Diuron & $\mathrm{mg} / \mathrm{L}$ & Metazachlor & $\mathrm{mg} / \mathrm{L}$ & Metolachlor \\
\hline 0.00005 & 94 & 0.00001 & 11 & 0.0005 & 33 & 0.0005 & 0 & 0.00005 & 11 \\
\hline 0.0005 & 64 & 0.0001 & -2 & 0.005 & 16 & 0.005 & 84 & 0.0005 & 47 \\
\hline 0.005 & 89 & 0.001 & 9 & 0.05 & 38 & 0.05 & 93 & 0.005 & 61 \\
\hline 0.05 & 91 & 0.01 & -3 & 0.5 & 86 & 0.5 & 93 & 0.05 & 44 \\
\hline 0.5 & 90 & 0.1 & 70 & 5 & 89 & 5 & 92 & 0.5 & 92 \\
\hline 5 & 93 & 1 & 85 & - & - & 50 & 93 & 5 & 95 \\
\hline
\end{tabular}

- not measured

\section{Discussion}

We found linear correlation between the frond number and the total chlorophyll content in case of the uncontaminated samples, however in some cases the contaminants did not cause any change in the frond number or biomass rather in the total chlorophyll content. In the preliminary experiments the effect of three chemical substances was investigated. In case of Na-diclofenac the effect of inhibition on the frond number was $\mathrm{H} \%=-1-68$, while on the total chlorophyll content $\mathrm{H} \%=8-88$ at $6.25-100 \mathrm{mg} / \mathrm{L}$ concentration range (Fig. 1a). In case of nicotine the inhibition in the frond number was $\mathrm{H} \%=-4-74$, while in the total chlorophyll content $\mathrm{H} \%=7-99$ at $0.1-1000 \mathrm{mg} / \mathrm{L}$ concentration range (Fig. $1 \mathrm{~b}$ ). In case of 3,4-dichlorophenol the effect of inhibition on the frond number was $\mathrm{H} \%=-5-71$, while on the total chlorophyll content $\mathrm{H} \%=5-92$ at $0.025-25 \mu \mathrm{g} / \mathrm{L}$ concentration range (Fig. 1c).

Therefore we found that determination of the total chlorophyll content was a more sensitive endpoint compared to the counting of the frond number.

Regarding diuron our tests showed similar inhibition values to the results of Teisserie et al. [46]. The applied toxicity endpoint was growth inhibition calculated from frond number data. They found the $\mathrm{EC}_{50}$ value to be $25 \mu \mathrm{g} / \mathrm{L}$ and the inhibition effect was detected at $5 \mu \mathrm{g} / \mathrm{L}$ concentration. Measuring the total chlorophyll content we detected $33 \%$ inhibition effect at $0.5 \mu \mathrm{g} / \mathrm{L}$ concentration level. Therefore at $0.5 \mu \mathrm{g} / \mathrm{L}$ diuron concentration the detected significant inhibition effect was higher than for Teiserie et al. [46] $(\mathrm{H} \%=33)$ therefore the LOEC value was considered to be $0.5 \mu \mathrm{g} / \mathrm{L}$. Teisserie et al. [46] reported about the increase of the chlorophyll content in the diuron solution compared to the control, but we could not detect this phenomenon. Metazachlor induced $84 \mathrm{H} \%$ at $5 \mu \mathrm{g} / \mathrm{L}$ concentration in our experiments, while Müller et al. [45] determined $\mathrm{EC}_{50}=2.8 \mu \mathrm{g} / \mathrm{L}$ measuring the frond area. We did not find any inhibition effect at $0.5 \mu \mathrm{g} / \mathrm{L}$ concentration, so further experiments are needed to determine the $\mathrm{EC}_{50}$ value between 0.5 and $5 \mu \mathrm{g} / \mathrm{L}$. Calculated from the measured data the LOEC value for metazachlor is $<5 \mu \mathrm{g} / \mathrm{L}$. For atrazine $\mathrm{EC}_{50}=56-153 \mu \mathrm{g} / \mathrm{L}$ data can be found in the current literature [44]. Based on our experiments measuring the frond number and the fresh weight, the LOEC value for atrazine is $100 \mu \mathrm{g} / \mathrm{L}$. Mihaich et al. (2009) determined $\mathrm{EC}_{50}=7.8-32 \mathrm{mg} / \mathrm{L}$ (Table 1) for bisphenol A measuring frond biomass and frond density, while the LOEC value is $12.5 \mathrm{mg} / \mathrm{L}$ according to our results. In terms of the population abundance [42] and the total frond area [41] $\mathrm{EC}_{50}$ values were $47.6 \mu \mathrm{g} / \mathrm{L}$ and $7.5 \mathrm{mg} / \mathrm{L}$ respectively for Na-diclofenac (Table 1). In our research the LOEC value is $3.125 \mathrm{mg} / \mathrm{L} . \mathrm{EC}_{50}$ value could not be determined, because the inhibition was not concentration dependent, the curve did not exhibit the typical sigmoid shape.

Brain et al. [38] determined the LOEC values of caffeine solutions, they found the LOEC value to be $118 \mu \mathrm{g} / \mathrm{L}-$ $4.746 \mathrm{mg} / \mathrm{L}$, while our result was $\mathrm{LOEC}=10 \mu \mathrm{g} / \mathrm{L}$ measuring the total chlorophyll content. In the USEPA/OPP, EFED; Pesticide Ecotoxicity Database [43] $\mathrm{EC}_{50}$ (population abundance) of acetochlor on Lemna gibba is $3.4 \mu \mathrm{g} / \mathrm{L}$. In our research the $\mathrm{LOEC}$ value was $0.05 \mu \mathrm{g} / \mathrm{L} . \mathrm{EC}_{50}$ (population abundance) of metolachlor on Lemna gibba was $21-95400 \mu \mathrm{g} / \mathrm{L}$. 

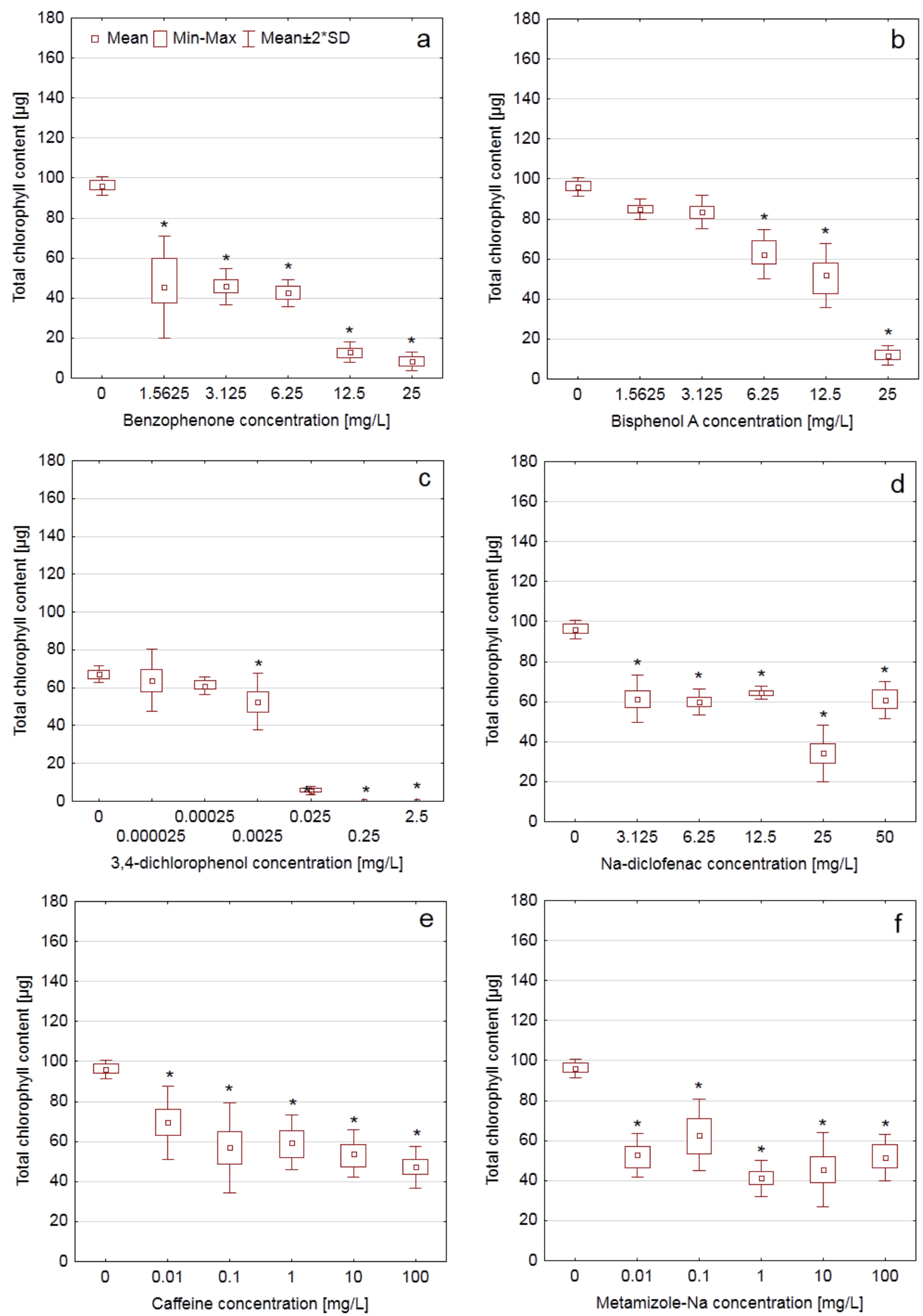

Fig. 2 BoxPlot diagrams of the effect of the applied emerging pollutants on the total chlorophyll content grouped by concentration. Significant inhibition effect is marked by asterisk (*). 

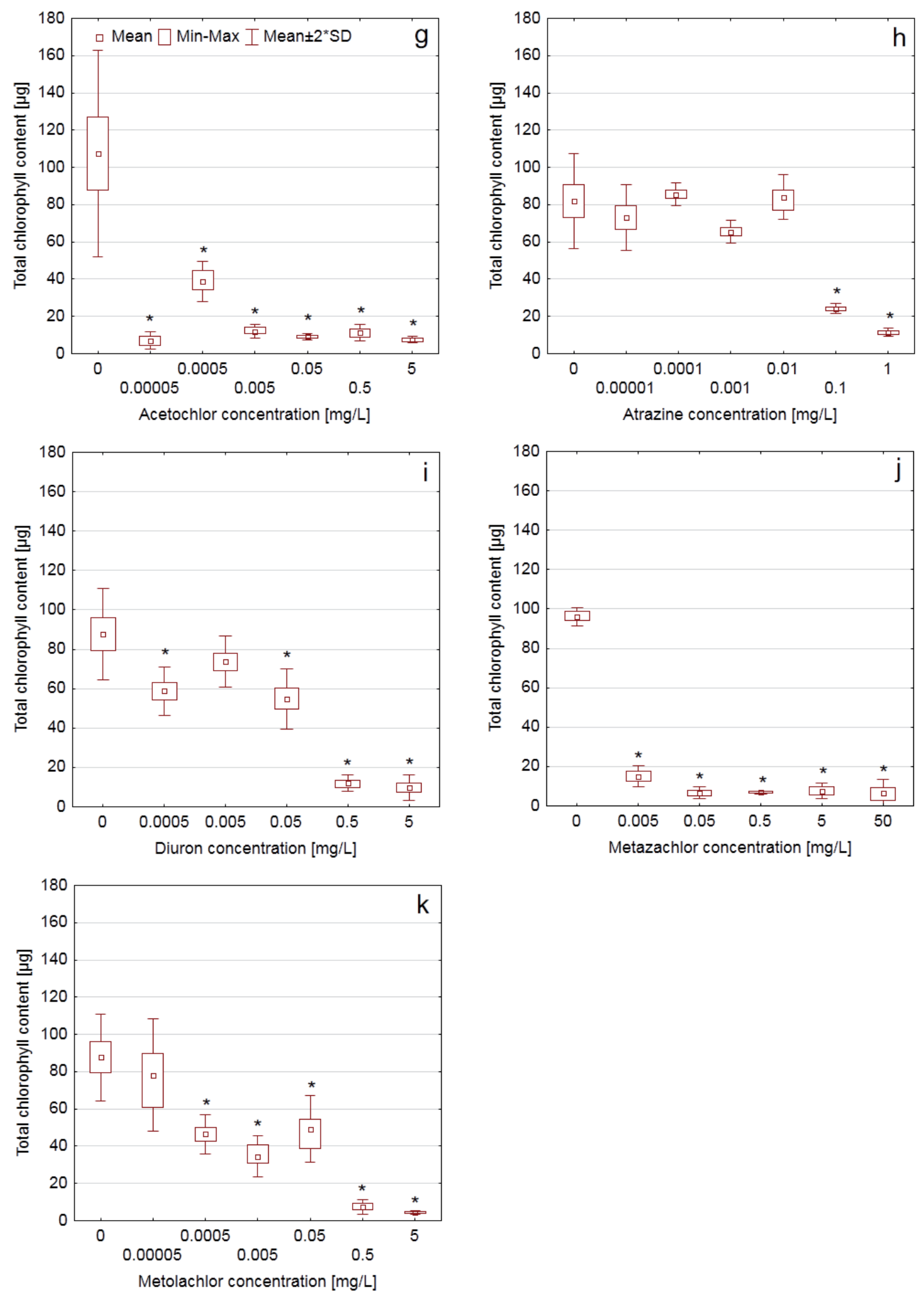

Fig. 3 BoxPlot diagrams of the effect of the applied emerging pollutants on the total chlorophyll content grouped by concentration. Significant inhibition effect is marked by asterisk (*). 
Based on the statistical analysis Table 4 shows the significant lowest observed effect concentrations of the applied micropollutants determined by the total chlorophyll content.

The measured data clearly show that the L. minor bioassay measuring the total chlorophyll content may be an appropriate and sensitive test method to detect the micropollutants in water matrices. In comparison with the routinely used test methods it proved to be more sensitive to $\mathrm{Na}$-diclofenac, nicotine and 3,4-dichlorophenol. Further research is needed for the investigation of the non-concentration depending effect and the mode of action.

Table 4 LOEC values of the total chlorophyll content assay of the tested chemical substances

\begin{tabular}{cc}
\hline Chemical substance & LOEC [mg/L] \\
\hline Acetochlor & 0.00005 \\
Metolachlor & 0.0005 \\
Diuron & 0.0005 \\
3,4-dichlorophenol & 0.0025 \\
Metazachlor & 0.005 \\
Caffeine & 0.01 \\
Metamizole-Na & 0.01 \\
Atrazine & 0.1 \\
Benzophenone & 1.5625 \\
Na-diclofenac & 3.125 \\
Bisphenol A & 6.25 \\
\hline
\end{tabular}

\section{Conclusion}

Duckweeds such as Lemna sp. are key components of freshwater ecosystems. These aquatic vascular plants are active components of many biogeochemical cycles and play vital role as primary producers. The genus Lemna has gained widespread acceptance also as tesorganism in environmental toxicology because of its small size, fast growth rate along with ease of culturing and handling. In ecotoxicity tests applying Lemna minor the most favourable measurement endpoints are the growth parameters (frond number, dry biomass), while the total chlorophyll content is less commonly determined.

Our results proved that Lemna minor bioassay based on determination of the chlorophyll content was highly sensitive to the tested micropollutants. The frond number and the chlorophyll content determinations were directly compared to each other and proved that the frond number was a less sensitive measurement endpoint in the case of nicotine, diclofenac and 3,4-dichlorophenol.

The lowest observed effect concentration values obtained suggested that the duckweed assay maybe used in water quality studies to monitor pesticides (acetochlor, atrazine, diuron, metazachlor, metolachlor) and industrial chemicals (3,4-dichlorophenol) at $\mu \mathrm{g} / \mathrm{L}$ concentration level. The Lemna minor bioassay based on determination of the total chlorophyll content may be an ideal test system due to its sensitivity, simple handling, easy culturing and cost-effectiveness.

\section{Acknowledgement}

The financial support of National Innovation Office (TECH_08-A4/2-2008-0161, CDFILTER and TECH_09A4-2009-0129, SOILUTIL project) is greatly acknowledged. The authors gratefully appreciate KISCHEMICALS Manufacturing and Mercantile LLC and Peters\&Burg Ltd. for supporting the atrazine, diuron, metolachlor and acetochlor test substances. We are grateful to Emese Vaszita for contribution to language editing of the manuscript. We acknowledge Sándor Kemény's contribution to statistical evaluation of the results.

\section{References}

[1] Kolpin, D. W., Furlong, E. T., Meyer, M. T., Thurman, E. M., Zaugg, S. D., Barber, L. B., Buxton, H. T. "Pharmaceuticals, hormones, and other organic wastewater contaminants in U.S. streams, 1999-2000: a national reconnaissance." Environmental Science \& Technology. 36 (18). pp. 1202-1211. 2002. DOI: 10.1021/es0200903

[2] Daughton, C. G. "Non-regulated water contaminants: emerging research." Environmental Impact Assessment Review. 24 (7-8). pp. 711 732. 2004. DOI: 10.1016/j.eiar.2004.06.003

[3] Barnes, K. K., Kolpin, D. W., Furlong, E. T., Zaugg, S. D., Meyer, M. T., Barber, L. B. "A national reconnaissance of pharmaceuticals and other organic wastewater contaminants in the United States - I groundwater." Science of the. Total Environment. 402 (2-3). pp. 192-200. 2008. DOI: $10.1016 /$ j.scitotenv.2008.04.028

[4] Loos, R., Gawlik, B. M., Locoro, G., Rimaviciute, E., Contini S., Bidoglio, G. "EU-wide survey of polar organic persistent pollutants in European river waters." Environmental Pollution. 157 (2). pp. 561-568. 2009. DOI: 10.1016/j.envpol.2008.09.020

[5] Deblonde, T., Cossu-Leguille, C., Hartemann, P. "Emerging pollutants in wastewater: A review of the literature." International Journal of Hygiene and Environmental Health. 214 (6). pp. 442-448. 2011.

DOI: 10.1016/j.ijheh.2011.08.002

[6] Santos, L. H. M. L. M., Gros, M., Rodriguez-Mozaz, S., Delerue-Matos, C., Pena, A., Barceló, D., Montenegro, M. C. B. S. M. "Contribution of hospital effluents to the load of pharmaceuticals in urban wastewaters: Identification of ecologically relevant pharmaceuticals." Science of the Total Environment. 461-462. pp. 302-316. 2013.

DOI: 10.1016/j.scitotenv.2013.04.077

[7] Ternes, T. A., Joss, A. "Human Pharmaceuticals, Hormones and Fragrances. The Challenge of Micropollutants in Urban Water Management." London: IWA Publishing. 2006.

[8] Oppenheimer, J., Stephenson, R., Burbano, A., Liu, L. "Characterizing the passage of personal care products through wastewater treatment processes." Water Environmental Research. 79 (13). pp. 2564-2577. 2007. DOI: $10.2175 / 106143007 \times 184573$

[9] Miège, C., Choubert, J. M., Ribeiro, L., Eusèbe, M., Coquery, M. "Removal efficiency of pharmaceuticals and personal care products with varying wastewater treatment processes and operating conditions - conception of a database and first results." Water Science \& Technology. 57 (1). pp. 49-56. 2008. DOI: 10.2166/wst.2008.823 
[10] Radjenovic, J., Petrovic, M., Barceló, D. "Fate and distribution of pharmaceuticals in wastewater and sewage sludge of the conventional activated sludge (CAS) and advanced membrane bioreactor (MBR) treatment." Water Research. 43 (3). pp. 831-841. 2009. DOI: $10.1016 /$ j.watres.2008.11.043

[11] Verlicchi, P., Galletti, A., Petrovic, M., Barceló, D. "Hospital effluents as a source of emerging pollutants: An overview of micropollutants and sustainable treatment options." Journal of Hydrology. 389 (3-4). pp. 416-428. 2010. DOI: 10.1016/j.jhydrol.2010.06.005

[12] Bergman, A., Heindel, J., Jobling, S., Kidd, K. A., Zoeller, R. T. "State of the science of endocrine disrupting chemicals." Toxicology Letters. 211. pp. S3-S3. 2012. DOI: 10.1016/j.toxlet.2012.03.020

[13] Rivera-Utrilla, J., Sánchez-Polo, M., Ferro-García, M. A., Prados-Joya, G., Ocampo-Pérez, R. "Pharmaceuticals as emerging contaminants and their removal from water. A review." Chemosphere. 93 (7). pp. 1268 1287. 2013. DOI: 10.1016/j.chemosphere.2013.07.059

[14] Lapworth, D., Baran, N., Stuart, M., Ward, R. "Emerging organic contaminants in groundwater: a review of sources, fate and occurrence." Environmental Pollution. 163. pp. 287-303. 2012. DOI: 10.1016/j.envpol.2011.12.034

[15] Post, G. B., Cohn, P. D., Cooper, K. R. "Perfluorooctanoic acid (PFOA), an emerging drinking water contaminant: A critical review of recent literature." Environmental Research. 116. pp. 93-117. 2012. DOI: 10.1016/j.envres.2012.03.007

[16] Park, J. S., Brown, M. T., Han, T. "Phenol toxicity to the aquatic macrophyte Lemna paucicostata." Aquatic Toxicology. 15. pp. 106-107. 2012. DOI: 10.1016/j.aquatox.2011.10.004

[17] Park, A., Kim, Y. J., Choi, E. M., Brown, M. T., Han, T. "A novel bioassay using root re-growth in Lemna." Aquatic Toxicology. 140-141. pp. 415-424. 2013. DOI: 10.1016/j.aquatox.2013.06.004

[18] Focazio, M. J., Kolpin, D. W., Barnes, K. K., Furlong, E. T., Meyer, M. T., Zaugg, S. D., Barber, L. B., Thurman, M. E. "A national reconnaissance for pharmaceuticals and other organic wastewater contaminants in the United States - II untreated drinking water sources." Science of the Total. Environment. 402 (2-3). pp. 201-216. 2008. DOI: 10.1016/j.scitotenv.2008.02.021

[19] Bolong, N., Ismail, A. F., Salim, M.R., Matsuura, T. "A review of the effects of emerging contaminants in wastewaters and options for their removal." Desalination. 239 (1-3). pp. 229-246. 2009. DOI: 10.1016/j.desal.2008.03.020

[20] Radić, S., Stipaničev, D., Cvjetko, P., Marijanović Rajčić, M., Širac, S., Pevalek-Kozlina, B., Pavlica, M. "Duckweed Lemna minor as a tool for testing toxicity and genotoxicity of surface waters." Ecotoxicology and Environmental Safe. 74 (2). pp. 182-187. 2011. DOI: 10.1016/j.ecoenv.2010.06.011

[21] Zezulka, S., Kummerova, M., Babula, P., Vanova, L. "Lemna minor exposed to fluoranthene: Growth, biochemical, physiological and histochemical changes." Aquatic Toxicology. 140-141. pp. 37-47. 2013. DOI: 10.1016/j.aquatox.2013.05.011

[22] Paczkowska, M., Kozlowska, M., Golinski, P. "Oxidative stress enzyme activity in Lemna minor L. exposed to cadmium and lead." Acta Biologica Cracoviensia Series Botanica. 49. pp. 33-37. 2007.

[23] Carvalho, R. F., Bromilow, R. H., Greenwood, R. "Uptake and translocation of non-ionised pesticides in the emergent aquatic plant parrot feather Myriophyllum aquaticum." Pest Management Science. 63 (8). pp. 798802. 2007. DOI: $10.1002 /$ ps. 1394

[24] Lemna EPA Test, OCSPP 850.4400: "Aquatic Plant Toxicity Test Using Lemna spp." [EPA 712-C-008]

[25] OECD 221, "Guideline, OECD Guidelines for Testing ofChemicals: Lemna sp. Growth Inhibition Test." 2006. DOI: 10.1787/9789264016194-en
[26] Drost, W., Matzke, M., Backhaus, T. "Heavy metal toxicity to Lemna minor: studies on the time dependence of growth inhibition and the recovery after exposure." Chemosphere. 67 (1). pp. 36-43. 2007. DOI: 10.1016/j.chemosphere.2006.10.018

[27] Dirilgen, N. "Mercury and lead: Assessing the toxic effects on growth and metal accumulation by Lemna minor:" Ecotoxicology and Environmental Safety. 74 (1). pp. 48-54. 2011. DOI: 10.1016/j.ecoenv.2010.09.014

[28] Horvat, T., Vidaković-Cifrek, Z., Oreščanin, V., Tkalec, M., PevalekKozlina, B. "Toxicity assessment of heavy metal mixtures by Lemna minor L." Science of The Total Environment. 384 (1-3). pp. 229-238. 2007. DOI: 10.1016/j.scitotenv.2007.06.007

[29] Gubbins, E. J., Batty, L. C., Lead, J. R. "Phytotoxicity of silver nanoparticles to Lemna minor L." Environmental Pollution. 159 (6). pp. 15511559. 2011. DOI: 10.1016/j.envpol.2011.03.002

[30] Juneau, P., Sumitomo, H., Matsui, S., Itoh, S., Kim, S.G., Popovic, R. "Use of chlorophyll fluorescence of Closterium ehrenbergii and Lemna gibba for toxic effect evaluation of sewage treatment plant effluent and its hydrophobic components." Ecotoxicology and Environmental Safety. 55 (1), pp. 1-8. 2003. DOI: 10.1016/S0147-6513(02)00130-6

[31] Gatidou, G., Stasinakis, A. S., Iatrou, E. I. "Assessing single and joint toxicity of three phenylurea herbicides using Lemna minor and Vibrio fischeri bioassays." Chemosphere. 119 (Supplement). pp. S69-S74. 2015. DOI: 10.1016/j.chemosphere.2014.04.030

[32] Geoffroy, L., Frankart, C., Eullaffroy, P. "Comparison of different physiological parameter responses in Lemna minor and Scenedesmus obliquus exposed to herbicide flumioxazin." Environmental Pollution. 131 (2). pp. 233-241. 2004. DOI: 10.1016/j.envpol.2004.02.021

[33] Kumar, K. S., Han, T. "Toxicity of single and combined herbicides on PSII maximum efficiency of an aquatic higher plant, Lemna sp." Toxicology and Environmental Health Sciences. 3 (2). pp. 97-105. 2011. DOI: $10.1007 / \mathrm{s} 13530-011-0084-3$

[34] Megateli, S., Dosnon-Olette, R., Trotel-Aziz, P., Geffard, A., Semsari, S., Couderchet, M. "Simultaneous effects of two fungicides (copper and dimethomorph) on their phytoremediation using Lemna minor." Ecotoxicology. 22 (4). pp. 683-692. 2013. DOI: 10.1007/s10646-013-1060-2

[35] Olette, R., Couderchet, M., Biagianti, S., Eullaffroy, P. "Toxicity and removal of pesticides by selected aquatic plants." Chemosphere. 70 (8). pp. 1414-1421. 2008. DOI: 10.1016/j.chemosphere.2007.09.016

[36] Cedergreen, N., Abbaspoor, M., Sorensen, H., Streibig, J. C. "Is mixture toxicity measured on a biomarker indicative of what happens on a population level? A study with Lemna minor:" Ecotoxicology and Environmental Safety. 67 (3). pp. 323-332. 2007.

DOI: $10.1016 /$ j.ecoenv.2006.12.006

[37] Gorzerino, C., Quemeneur, A., Hillenweck, A., Baradat, M., Delous. G., Ollitrault, M., Azam, D., Caquet, T., Lagadic, L. "Effects of diquat and fomesafen applied alone and in combination with a nonylphenol polyethoxylate adjuvant on Lemna minor in aquatic indoor microcosms." Ecotoxicology and Environmental Safety. 72 (3). pp. 802-810. 2009. DOI: 10.1016/j.ecoenv.2008.08.001

[38] Brain, R. A., Johnson, D. J., Richards, S. M., Hanson, M. L., Sanderson, H., Lam, M. W., Young, C., Mabury, S. A., Sibley, P. K., Solomon, K. R. "Microcosm evaluation of the effects of an eight pharmaceutical mixture to the aquatic macrophytes Lemna gibba and Myriophyllum sibiricum." Aquatic Toxicology. 70 (1). pp. 23-40. 2004. DOI: 10.1016/j.aquatox.2004.06.011

[39] Lichtenthaler H. K. "Chlorophylls and carotenoids: Pigments of photosynthetic biomembranes." Methods in Enzymology. 148. pp. 350-382. 1987. DOI: 10.1016/0076-6879(87)48036-1 
[40] Mihaich, E. M., Friederich, U., Caspers, N., Hall, A. T., Klecka, G. M., Dimond, S. S., Staples, C. A., Ortego, L. S., Hentges, S. G. "Acute and chronic toxicity testing of bisphenol A with aquatic invertebrates and plants." Ecotoxicology and Environmental Safety. 72 (5). pp. 1392-1399. 2009. DOI: $10.1016 /$ j.ecoenv.2009.02.005

[41] Cleuvers, M. "Aquatic ecotoxicity of pharmaceuticals including the assessment of combination effects." Toxicology Letters. 142 (3). pp. 185194. 2003. DOI: 10.1016/S0378-4274(03)00068-7

[42] Quinn, B., Schmidt, W., O’Rourke, K., Hernan, R. "Effects of the pharmaceuticals gemfibrozil and diclofenac on biomarker expression in the zebra mussel (Dreissena polymorpha) and their comparison with standardised toxicity tests." Chemosphere. 84 (5). pp. 657-663. 2011. DOI: $10.1016 /$ j.chemosphere.2011.03.033

[43] U. S. Environmental Protection Agency Ecotox Database. [Online] Available from: http://cfpub.epa.gov/ecotox/ [Accessed: 23th February 2015]
[44] Kirby, M. F., Sheahan, D. A. "Effects of atrazine, isoproturon, and mecoprop on the macrophyte Lemna minor and the alga Scenedesmus subspicatus." Bulletin of Environmental Contamination and Toxicology. 53 (1). pp. 120-126. 1994. DOI: 10.1007/BF00205148

[45] Müller, R., Berghahn, R., Hilt, S. "Herbicide effects of metazachlor on duckweed (Lemna minor and Spirodela polyrhiza) in test systems with different trophic status and complexity." Journal of Environmental Science and Health, Part B: Pesticides, Food Contaminants, and Agricultural Wastes. 45 (2). pp. 95-101. 2010. DOI: 10.1080/03601230903471829

[46] Teisseire, H., Couderchet, M., Vernet, G. "Phytotoxicity of diuron alone and in combination with copper or folpet on duckweed (Lemna minor)." Environmental Pollution. 106 (1). pp. 39-45. 1999.

DOI: 10.1016/S0269-7491(99)00066-4 